\title{
Teknologikritik og reformisme
}

Nils Hybel

\section{Den klassiske og den ny reformisme}

Det gærer på venstrefløjen. Frustrationen over revolutionens udebliven og den kapitalistiske krises skærpelse har udløst nye politiske bevægelser og en ny teoretisk kritik af kapitalismen. 1970'erne har været bevægelsernes årti. Bevægelser som har søgt at drage demarkationslinier til den revolutionære marxistiske venstrefløj og til den traditionelle reformistiske arbejderbevægelse. Die Grüne kalder de sig i Vesttyskland, græsrodsbevægelsen kaldes de i Danmark.

Hensigten med dette essay er et forsøg på kritik af nogle af disse bevægelsers videnskabelige fortalere. At påvise nogle almene teoretiske og strategiske implikationer af den argumentation, som fremføres fra dette hold angiveligt mod den kapitalistiske produktionsmåde og den reformistiske arbejderbevægelse, de facto mod den revolutionære marxistiske teori.

Det er nu snart to hundrede år siden den kapitalistiske produktionsmåde for første gang blev angrebet for sine teknologiske konsekvenser. Teknologikritikken er ikke noget nyt fænomen, skønt netop teknologikritikken er de nye grønne bevægelsers og de her diskuterede forfatteres Andre Gorz, Rudolf Bahro og Otto Ullrich - fællesnævner.
For mig at se eksisterer der en meget direkte identitet mellem den reformisme, som artikuleres af græsrødderne og deres videnskabelige fortalere, og den som vi kender fra den såkaldte maskinstormerbevægelse i kapitalismens barndom. Det er en reformisme med udgangspunkt i kritikken af konsekvenserne af den kapitalistiske produktionsmådes intensive akkumulation. Heroverfor står en reformisme med et andet teknologikritisk indhold. Mens maskinstormerne og græsrødderne rettede og retter angreb mod konsekvenserne af den intensive akkumulation, var og er den klassiske reformisme, repræsenteret af den socialdemokratiske politiske og faglige bevægelse, tilhængere af denne akkumulationsform, qua dens fors $\varnothing \mathrm{g}$ på forsvar mod den ekstensive akkumulations konsekvenser. På trods af at jeg ser en umiddelbar identitet mellem de tidligste reformister, og de jeg kalder nyreformisterne, er den følgende diskussion holdt indenfor rammerne af en konfrontation mellem den klassiske og den ny reformisme.

Inden jeg giver mig i kast med kritikken af nyreformisternes teknologikritik, skal jeg understrege, at jeg anser reformismen som en i og for sig naturlig del af den historiske proces, 
idet reformismen, som bevidsthedsform og politisk bevægelse, er en konsekvens af kapitalens udvikling. Den er udtryk for arbejderklassens forsvarsvilje mod det kapitalistiske herredømmes konsekvenser, som kan implicerer momenter af den revolutionære udvikling, omend reformismen i teorien først og fremmest bidrager til en forlængelse af kapitalismens eksistens. De konsekvenser af de underliggende sagsforhold eller de overfladefænomener, som reformisterne retter deres kritik imod kan være reelle nok. Det kan være virkelige problemer, som det ikke nytter, at revolutionære afviser. Vor indsats er at forbinde disse overfladeproblemer med deres væsensgrund dvs. at afdække, om det er proletariatets problemer eller ej, og påvise hvordan proletariatets problemer kun kan $1 \varnothing-$ ses radikalt. Dvs. ved at gå til ondets rod.

Reformistisk politik udvikles direkte affødt af kapitalens herredømme, af kapitalens lovmæssige udvikling. Historisk har vi set, hvordan den absolutte merværdiproduktion medførte arbejderbevægelsens opkomst som arbejderklassens reaktion mod denne udbytningsform. Vi har set, hvordan arbejderklassens organisering omkring lønkampen og arbejdsdagens længde opstod som nødvendigt forsvar mod den kapitalistiske produktions terror i det 19. århundrede. $\mathrm{Og}$ vi har set, hvordan denne kamp ledte til en tilsyneladende sejr, til 8 timers arbejdsdag og stigende lønninger; efterhånden og $\mathrm{i}$ overensstemmelse med kapitalens in- tensive akkumulationsform, og med udviklingen af konsummiddelindustrien i det 20. århundrede.

Den absolutte udbytning af arbejdskraften resulterede i sult, elendige boligforhold, sygdom og tidlig død. Den var den kapitalistiske produktions bidrag til det forrige århundredes arbejderklasse. Det var mod disse konsekvenser af den kapitalistiske produktion, at arbejderklassen rejste sig og organiserede sig til forsvar.

Når vi betragter den udviklede kapitalistiske del af verden - Vesteuropa, Nordamerika, Australien og Japan - i dag, ser vi, hvordan denne forsvarskamp tilsyneladende er lykkedes. Trods den indeværende krise er arbejderklassens reproduktionsvilkår målt med borgerlig målestok steget uhyre, langt ud over hvad tidligere generationer af arbejderklassen havde mulighed for at forestille sig. Men det er ikke arbejderklassens reformistiske kamp, som er årsagen til denne udvikling. Nej, det er den kapitalistiske produktions lovmæssige udvikling, som vi kan 'takke' for disse civiliserende tiltag.

For den, der er i stand til at læse Marx uden at lade sig distrahere af hans mange konkrete vurderinger af kapitalismens samtidige og fremtidige følger, men som holder sig til hans alderdoms geniale teoriudvikling om den kapitalistiske produktions almene logik, er arbejderklassens reformistiske sejre forståelige ikke som sejre, men som nødvendige konsekvenser af den abstrakte logik 
kapitalen implicerer, og som altså Marx indså.

Den terror mod arbejderklassen, som den ekstensive akkumulation medførte, afløstes nødvendigvis af den intensive akkumulations humane implikation, gennem den i princippet uendelige højnelse af arbejdets produktivitet, og kapitalens anvendelse af arbejderklassen som realiseringsgrundlag for den producerede merværdi.

Den ekstensive akkumulations rovdrift på arbejderklassen var et subjektivt problem for arbejderklassen, men det var et objektivt problem for kapitalen. Den samfundsmæssige totalkapital tåler ikke destruktion af det for merværdiproduktionen nødvendige menneskelige reservoir. Problemets løsning må forstås ud fra kapitalens natur, ud fra den dominerende samfundsmæssige magt kapitalen, kapitalkonkurrencen og den i rammerne af denne historisk kontinuerligt stadigt mere dominerende intensive akkumulation.

\section{Nyreformisternes angrebsfelter}

Men hvad har da denne tendentielt historisk stigende intensive akkumulation medført? Ja, den har som allerede omtalt medført et efter borgerlig målestok stadigt voksende reproduktionsniveau for arbejderklassen. $\mathrm{Og}$ den har yderligere abstraktliggjort udbytningen. Den udbytning, som under den ekstensive akkumulation kan sanses, transformeres på det umiddelbart sanselige plan til at blive oplevelsen af en stadig større ind- og underordning i ubestemmelige produktions- og livssammenhænge. Der er her udtrykkeligt tale om fænomener eller konsekvenser af kapitalens magt, som er blevet forandret, og måske p.g.a. teknificeringen af produktions- og livssammenhængene nu sanses stærkere end tidligere. Kapitalens herredømme er ikke ændret i sit væsen, blot fordi herredømmet teknificeres. Den abstrakte samfundsmæssige fremmedbestemmelse har eksisteret så længe som kapitalen, og det skønt netop teknificeringen og hierarkiseringen af produktions- og livssammenhængene er det ene af de to angrebsfelter, hvor de ny reformister sætter ind.

Deres andet angrebsfelt, naturog ressourcedestruktionen og kvantificeringen af arbejderklassens reproduktion, er den anden generelle konsekvens af den intensive akkumulations dominans. Mens de klassiske reformister hovedsageligt rettede deres kritik mod destruktionen af de levende arbejdskræfter, dvs. den destruktion som følger af den absolutte udbytningsform, går de nye reformister i rette med på den ene side teknificeringen og hierarkiseringen af den kapitalistiske produktions- og reproduktionsproces og på den anden side natur- og ressourcedestruktionen, samt den kvantitative udvidelse af arbejderklassens reproduktion.

Denne kritik af samfundsmæssige fremtrædelsesformer leder hen 
mod to almene forhold ved den kapitalistiske $\varnothing$ konomi. 1. Det værdimæssige akkumulationsprincip, værdiøgningen for værdiøgningens egen skyld, hvilken tilsyneladende bryder med enhver form for stoflig kvalitet og evindeligt $\varnothing$ ger stofskiftet mellem natur og menneske.

2. Koncentrationsprincippet, kapitalens værdimæssige koncentration, som de ser absolut omsat til stoflig centralisation - storindustri - og hierarkisk organisering af arbejdsprocessen.

Det er ikke svært at udpege, hvor de ny reformisters kortslutninger begynder, trods det, at de i modsætning til de klassiske reformister endnu ikke i væsentligt omfang har udviklet en egentlig revisionistisk teori, som baggrund for deres overfladekritik af kapitalismen og deres deraf følgende reformiver. Hos Ullrich, Bahro og Gorz indskrænker den teoretiske indsats sig til ret indlysende og uinteressante påpegninger af modsatrettede ytringer $\mathrm{i}$ Marx' enorme litterære produktion. Nyreformisterne har, ligesom de klassiske reformister, en manglende forståelse af den modsætning som ligger i varens natur, som bytte- og brugsværdi. De har en forståelse af varen, hvor værdi og brugsværdi smelter sammen, og de er dermed ikke istand til at udsondre relationen mellem den kapitalistiske produktions værdimæssige tvangslogik og den stoflige udvikling.

\section{Vækstøkonomi}

\section{og kapitalrationalitet}

Denne manglende analytiske skarphed får nyreformisterne til at drage en umiddelbar parallel mellem kapitalens netop abstrakte værdimæssige akkumulationslovmæssighed og et konkret stadigt stigende stofskifte mellem natur og menneske. De tror, at udbytningen af levende arbejde og den følgende akkumulation af dette i abstrakt form som kapital nødvendigvis fører til en kvantitativ vækst af indhugget i den eksterne naturs råstofreservoir. Med Marx i hånden belærer de os om, at den abstrakte akkumulation tilsidesætter den målrettede konkrete stoflige produktion, samtidig med at de afstikker en konkret stoflig målrettethed for den kapitalistiske produktion, som groft sagt implicerer en ekstrapoleret vækst af indhugget i de naturlige ressourcer: en ubetinget $\varnothing$ delæggelse af naturen og en kvantitativ udvidelse af arbejdskraftens reproduktion med kun naturødelæggelsen som grænse.

Det er empirisk korrekt, at kapitalismen i forhold til tidligere samfundsmæssige former har medført en materiel kvantitativ ekspansion af uhyre omfang. Mængden af materielle goder, såvel produktive som konsumtive, har været eksplosionsagtigt stigende siden kapitalismens opkomst; med klare $\varnothing$ kologiske problemer til følge. Men det betyder ikke, at dette stoflige ekspansionsprincip i sig selv er kapitalens prin- 
cip. Det er en fremtrædelsesform for kapitalens princip, ligesom det i mindre grad godt nok også var en fremtrædelsesform for feudalismens væsen. Kapitalen er ikke underlagt et stofligt ekspansionsprincip. Princippet om stadigt stigende vækst i det materielle stofskifte mellem menneske og natur er et overhistorisk princip, som i større eller mindre grad er en fremtrædelsesform for den enkelte samfundsmæssige forms væsenssammenhænge. Økonomisk vækst, som det hedder i revisionistisk terminologi, med følgende $\varnothing$ kologiske skader, kan således f.eks. konstateres i den vesteuropæiske feudalismes glansperiode, tiden fra 1000 til 1300 .

Lidt mere omhyggelighed i omgangen med den marxske teori om den kapitalistiske produktionslogik viser, at netop brugsværdiens underordning under bytteværdien kan resultere i snart sagt en hvilken som helst brugsværdiproduktion, og ikke nødvendigvis den kvantitative udvikling af stofskiftet, som vi hidtil har oplevet, og ej heller nødvendigvis $\mathrm{i}$ en kun kvantitativ udvikling af arbejderklassens reproduktion. Hvilke konkrete brugsværdier kapitalen producerer som underlag for sin abstrakte merværdihunger, hvor meget produktionen gør indhug i naturressourcerne, i hvilket omfang de producerede produkter og arbejderklassens reproduktion kan siges at være underlagt kvantitative stoflige kriterier, afhænger til enhver tid af de på et givet tidspunkt samfunds- mæssigt satte produktive og reproduktive behov.

I den marxske teoridannelse om kapitalismens væsenssammenhænge er vareformen det formerende analytiske middel. Hvis vi forlader overfladens tåger, og dykker ned mod det, som reformisterne måske gerne vil forstå, ser vi, at de kapitalistiske modsætninger udspringer af de samfundsmæssige relationers binding til vareformen, og at varen som bekendt er af tvetydig natur. Den er bytteværdi og den er brugsværdi. Det betyder, at før den kapitalistiske udbytning kan finde sted, må der være umiddelbart brugelige produktionskomponenter tilstede, brugelige i den forstand at de kan opfylde givne samfundsmæssige behov. Før den kapitalistiske merværdi kan dannes gennem arbejdskraftens dobbelte og særlige brugsværdi, er det brugsværdimæssige anarkistiske samfundsmæssige behov den givne forudsætning for produktionen af såvel merværdi som varer. Værdisiden - udbytningen og akkumulationslogikken - har som forudsætning brugsværdien; de givne samfundsmæssige behov.

Hvis vi betragter de umiddelbart givne samfundsmæssige behov, det stoflige grundlag for profitmaximeringen, i perioden omkring den klassiske reformismes opkomst, er den smukke kapitalistiske modsætning mellem enkeltkapital og samfundsmæssig totalkapital i forbindelse med arbejdskraftens udbytning iøj- 
nefaldende. Selv om enhver enkelt kapitalist naturligvis helst aflønner sine arbejdere med så lille en løn som muligt, er det i den samfundsmæssige totalkapitals, og dermed også den enkelte kapitalist interesse, at den samfundsmæssige totalarbejder aflønnes så godt som muligt, da arbejderen indgår som realiseringsbetingelse for hver enkelt kapital. Kapitalen skal som bekendt ikke blot producere mest mulig merværdi, den skal også have merværdien realiseret. Udviklingen af den til dette formål adækvate industri - konsummiddelindustrien - var et samfundsmæssigt behov for kapitalen - den samfundsmæssige totalkapital - objektivt og subjektivt for arbejderklassen.

Hvis vi betragter de aktuelle samfundsmæssige behov, som kan blive grundlaget for en $\emptyset$ get profitproduktion og højnet arbejdsproduktivitet, synes en række af de områder nyreformisterne anviser at være adækvate samfundsmæssige behov. De er i så henseende måske forudseende, sådan som de klassiske viste sig at være det på langt sigt. På den anden side af det konjunkturelle hul kapitalismen er inde i nu, forekommer den alternative bløde teknologi mulig. Vedvarende energiudvikling, $\emptyset$ kologisk balanceteknologi og kvalitativt bedre brugsværdier er altsammen områder eller behov, der kan dækkes af en efter krisen restitueret kapital. Hvilket ikke i sig selv, når denne teknologi tages i anvendelse - i det omfang den ikke allerede er taget i anvendelse - nødvendigvis fører til et forøget stofskifte. En positiv udvikling af profitproduktionen og højnelser i arbejdets produktivitet medfører ikke nødvendigvis en forøgelse af stofskiftet. Og det specielt ikke i den udstrækning en sænkning, respektiv en nulstilling af dette bliver et samfundsmæssigt behov, et absolut behov for kapitalens overlevelse. Hvilket ufravigeligt behov for den samfundsmæssige totalkapital bliver opnåeligt i takt med og afledt af den historisk stigende kapitalkoncentration. Mens restituering og beskyttelse af det fysiske miljø og de naturgivne ressourcer samt ressourceknapheden i sig selv også uden en yderligere kapitalkoncentration allerede for en række enkeltkapitaler har en klar økonomisk betydning, hvilket i det mindste Gorz kan indse.

Det er en floskel, når nyreformisterne kan mene, at den kapitalistiske merværdiproduktion baserer sig på udelukkende kvantitativ udvidelse af den samfundsmæssige brugsværdikreds. Det er rigtigt, at der kan scores ekstra profitter på forringelser af de producerede varer, men det er ikke det almene princip. Det almene princip i den kapitalistiske $\varnothing$ konomi er, at konkurrencen udfolder sig ud fra værdien, men at værdien er båret af brugsværdien, at der er en sammenhæng mellem en vares værdi, dens pris og dens brugsværdis kva- 
litet. Hverken i de produktionsmæssige eller i de konsumtionsmæssige behovssammenhænge er det således, at det på langt sigt for en producent kan lade sig gøre at hæve sin kapitals profitabilitet gennem forringelser af den producerede vares kvalitet, gennem en af denne vej simpel sænkning af værdiindholdet i den pågældende vare. Den eneste farbare vej for en højnelse af kapitalens profitabilitet er kapitalkonkurrencens almene lov om innovation af arbejdsprocessen og cirkulationen. Dvs. sænkning af varens værdiindhold gennem teknologisk indsats, og ikke gennem simpelt udtræk af værdi fra varen gennem sænkning af dens brugsværdis kvalitet. Betragtninger af denne art hos nyreformisterne er nok ikke i egentlig forstand cirkulationistiske omend de giver associationer til merkantilismens handelskapitalistiske profiteringsmåde, det simple snyderi. De hænger sammen med den udialektiske opfattelse af relationen mellem kapitalens værdimæssige logik og dens brugsværdimæssige udvikling, som allerede er anført.

Udviklingen af en brugsværdimæssig kvalitativt bedre produktion er en følge af kapitalens kvantitative værdimæssige princip. Selv om den kapitalistiske producent i princippet er ligeglad med hvilken brugsværdi han producerer, og i hvilken brugsværdimæssig kvalitet den produceres, idet merværdiproduktionen er determinerende for hans handling, så skal det ikke forlede en til at tro, at man kan producere en hvilken som helst brugsværdi i en hvilken som helst kvalitet efter forgodtbefindende. Princippet om brugsværdiens kvalitative udvikling, som har logisk indbyrdes relation til merværdiproduktionen ser jeg ingen grund til at tro, hverken vil aftage eller forsvinde i den videre kapitalistiske udvikling. Tværtimod tror jeg, at det vil accentueres i fremtiden under indtryk af den tiltagende ressourceknaphed, og arbejderklassens efterhånden kvantitativt mættede reproduktion.

Nyreformisterne forfærdes med god grund af den kapitalistiske produktions konsekvenser. Af naturdestruktionen og den kvalitative udvikling af produktions- og reproduktionssammenhængene. Der er grund til at vende sig mod disse konsekvenser, men der er ikke grund til at tro, at den kapitalistiske produktion ikke indretter sig mod en imødegåelse af dem. Kapitalens styrende abstrakte kvantitative akkumulationsprincip kan udmærket tænkes at formere en stoflig kvalitativ produktion, som tvunget af ydre omstændigheder tilgodeser $\varnothing$ kologiske hensyn. Den har allerede gjort det, og gør det i stigende omfang.

\section{Storindustri og kapitalrationalitet}

Jeg har generelt de samme overvejelser at tilføje det tidligere nævnte andet almene forhold ved den kapitali- 
stiske $\varnothing$ konomi som nyreformisterne i deres kritik griber fat $\mathrm{i}$ - kapitalens koncentrationsprincip.

Her angriber de igen grundigt en stoflig konsekvens - storindustrien og forbinder den uformidlet med et abstrakt værdimæssigt princip. Uden iøvrigt at gå teoretisk til værks gennem eksplicitering af følgende forbindelse anser de kapitalens værdimæssige koncentration for entydigt ensbetydende med den stoflige produktionsstrukturs centralisering og produktionsprocessens hierarkisering, gennem fortsat uendelig opsplitning af ånds- og håndsarbejde.

Nyreformisterne er imidlertid tæt på forståelsen af denne problemstilling. De kritiserer nemlig udmærket den storindustrielle produktionsorganiserings samfundsmæssige kontraproduktivitet. Hvordan denne særlige produktionsorganisering har grænser for en fortsat højnelse af arbejdets produktivitet. Men i og med de ikke forstår kapitalens almene struktur, bliver opbrydningen af storindustrien med henblik på højnelse af arbejdsproduktiviteten i et mere decentraliseret og mindre arbejdsdelt regi for dem ensbetydende med det kapitalistiske produktionsforholds ophævning.

Det er imidlertid overhovedet ikke en forudsætning for opbrydningen af den storindustrielle produktionsorganisering. Netop fordi kapitalen alt andet lige udvikler sig mod større og større værdimæssig koncentration, udvikles mulighederne for en samfundsmæssig rationalitet sig tilsvarende. Efterhånden som den $\varnothing \mathrm{ko}-$ nomiske konkurrence indsnævres mellem færre og færre enkeltkapitaler, tilgodeses mulighederne - subsidiært udvikles tvangsmæssigheden af at højne arbejdets produktivitet gennem omstruktureringer af den eksisterende produktionsstruktur og produktionsproces.

Nyreformisterne giver i deres bøger mange eksempler herpå. Hvordan den vertikalt arbejdsdelte arbejdsproces for den enkelte kapitalist, hvad arbejdsprtoduktiviteten angår, har bestemte grænser. Og set fra et samfundsmæssigt synspunkt, hvordan den centraliserede produktionsstruktur tilsvarende medfører, hvad de kalder kontraproduktivitet, forringelser i arbejdets produktivitet.

Hvad den vertikalt arbejdsdelte produktionsproces angår - den arbejdsproces som er funderet $i$ en opdeling af ånds- og håndsarbejde mener f.eks. Ullrich med Mumford, at der fra civilisationens begyndelse er udviklet to uens teknologier. Den ene demokratisk og decentral den anden despotisk og centralistisk. Den ene baseret på en forening af håndsog åndsarbejde den anden på en deling, hvor sidst nævnte knytter sig til udbytningen og rigdommens koncentration. Den centraliserede produktionsstruktur udvikler sig således i overensstemmelse med den vertikalt arbejdsdelte produktionsproces, som i kapitalismen har fået sin fulde udfoldelsesmulighed. Denne opfattelse 
af affinitet mellem den abstrakte rigdoms koncentration og teknologiens centralisation må empirisk alt andet lige siges at være korrekt hvad angår den hidtil gennemlevede kapitalistiske epoke. Men jeg vil sætte et stort spørgsmålstegn ved, om denne affinitet vil fortsætte under den videre udvikling af kapitalismen, p.g.a. de klart tilstedeværende problemer for en højnelse af arbejdets produktivitet som den vertikale arbejdsdeling medfører.

Den ekstreme deling af ånds- og håndsarbejde betyder en dekvalificering af arbejderen såvel i arbejdsprocessen som afledt heraf $i$ arbejderens totale reproduktion af sit liv. Ikke alene bindes arbejderens produktive potentialer gennem den vertikalt arbejdsdelte arbejdsproces' tilegnelse af kun dele af hans potentielle produktivkraft. Gennem den fordummende specialisering til et individ, der kun har mulighed for at udøve enkelte arbejdsfunktioner, berøves han tillige evnen og muligheden for at forstå sin egen reproduktion, som han da må have tilført gennem andres her til svarende produktive samfundsmæssige funktioner.

Imidlertid ved vi empirisk, at denne udviklings himmelflugt allerede er blevet bremset. Kapitalen har vist sin $\varnothing$ konomiske fleksibilitet og gjort enhver almen teori om arbejdskraftens dekvalificering til skamme. Taylorsystemets i så henseende fuldendelse af denne proces har allerede vist sig urentabel for kapitalen, hvilket under sidste højkonjunktur konkret gav sig udslag i nye managementsteorier omfattende tværfaglighed og problemorienteret selvstyre i produktionsprocessen og i uddannelsen af arbejdskraften.

Den ekstremt vertikalt opdelte arbejdsproces medfører nemlig ikke alene en mængde irrationaliteter i form af den før nævnte binding af de enkelte arbejdskræfters produktivkræfter, hvilke i stigende grad bliver kapitalirrationelle med den abstrakte rigdoms voksende koncentration. Den implicerer også en subjektiv faktor med hæmmende virkning for udviklingen af arbejdets produktivitet qua arbejderens manglende motivation for arbejdet. Et forhold den kendte sovjetkritikker Cornelius Castoriadis anser for en klar kontraproduktiv konsekvens af den stærkt hierarkiserede og »taylorriserede « produktionsorganisering. Den med Mumford såkaldte demokratiske og decentrale teknologi skulle for mig at se i takt med kapitalens fortsatte værdimæssige koncentration udmærket kunne udvikles langt yderligere, end tilfældet allerede er, under kapitalistisk produktionsmåde.

Dette fordi værdikoncentrationen tilsvarende omformer den kapitalrationalitet, som den centraliserede stoflige produktionsstruktur hidtil har indebåret, til at blive irrationel. Den bliver ensbetydende med en sænkning af arbejdets produktivitet i samfundet. Den decentralisering af 
produktionsstrukturen, som nyreformisterne anser for samfundsmæssigt påkrævet, og hvilken de selv udmærket ud fra samfundsmæssige $\varnothing$ konomisk rationelle hensyn argumenterer for, anser jeg for en kapitallogisk konsekvens af en yderligere værdimæssig koncentration i samfundet. I det omfang den indeværende krise på sædvanlig vis resulterer i en øget værdimæssig koncentration af kapitalen, vil en række af de set ud fra et samfundsmæssigt totalkapitalistisk, men iøjeblikket ikke enkeltkapitalistisk, synspunkt eksisterende kontraproduktive konsekvenser af den centraliserede produktionsstruktur omformes til at blive en ikkekapitalreproduktiv stoflig produktionsstruktur, hvilket nødvendigvis må medfører en ændring af denne konkrete stoflige struktur.

Jeg har nu givet omridsene af forståelsen for, hvordan de nye reformister ligesom de klassiske gennem deres kritik af den kapitalistiske produktions umiddelbare stoflige struktur p.g.a. deres manglende analyse af de kapitalistiske væsenssammenhænge, generelt kun i deres kritik synes at foregribe en mulig fremtidig udvikling af kapitalismens stoflige produktionssammenhænge. Hermed være ikke sagt, at ethvert af deres forslag til konkret ændring af de samfundsmæssige stoflige produktionssammenhænge vil blive udviklet af kapitalen. En vurdering heraf er af så detaljeret karakter, at den ligger uden for hensigten med og mine muligheder i nærværende sammenhæng.

\section{Reformistisk og revolutionær teknologikritik}

Derimod vil jeg fremføre et synspunkt på nyreformisternes teknologikritik, som umiddelbart logisk synes at kollidere med de allerede fremførte betragtninger. I den nyreformistiske teknologikritik er indeholdt umiskendelige tegn på nostalgi. Det er min generelle vurdering, at den på en gang analytisk implicerer forudsigelser af væsentlige dele af fremtidens kapitalistiske teknologi samtidigt med, at den positivt vender sig mod fortidens - merkantilismens og den tidlige kapitalismes teknologi. Den omfatter den småborgerlige vision om en skøn forening af autonomi og heteronomi.

Kravet om nedbringelse af stofskiftet, hvilket i sig selv er en hån mod den tredie verdens sultende masser, og vel også dele af den første verdens mest forarmede folk især i den indeværende krise, decentralisering af produktionsstrukturen, forening af hånds- og åndsarbejde og den samfundsmæssige planstyring af $\varnothing$ konomien, refererer for mig at se direkte tilbage i tid, samtidigt med at det er et krav om yderligere perfektionering af den menneskelige teknologi til 'beherskelse' af naturen, ud over hvad vi allerede har oplevet.

De grønne nyreformisters fjendtlige forhold til de lyserøde klassiske 
reformister er i førstnævnte overfladiske selvforståelse selvfølgelig. Men i grunden, bag overfladen er den masochistisk. De kritiserer, som de klassiske reformister, kapitalismen ud fra overfladiske betragtninger, og de når frem til 'løsningsforslag', der er lige så kapitaladækvate som de klassiske reformisters. De ser ikke den elastisitet, som den kapitalistiske produktionslogik indebærer. De ser ikke, at skønt den kapitalistiske produktion historisk har udviklet sig fra ekstensiv til intensiv akkumulation, og således imødegået de problemer de gamle reformister fixerede, samtidigt med at de nye reformisters problemer produceredes, så kan valoriseringsmotivet og kapitalkonkurrencen i fremtiden udmærket stille denne historiske og teoretiske systematik på hovedet. Er den indeværende krises følge måske ikke bl.a. den historiske artikulation af en, efter en lang periode med relativ udbytning, tilbagevenden af den absolutte udbytningsform, som set fra en reformistisk position netop accentuerer den klassiske reformismes betydning.

Tilsvarende er deres kritik af marxismen og marxisterne uholdbar. De kritiserer marxisterne for at være produktivkraftfetischister, for kun at være interesseret i undersøgelsen af den materielle produktion og dennes $\emptyset$ konomiske logik samtidig med, at deres egene bidrag udelukkende tager sigte mod kritikken af fremtrædelsesformer for den kapitalistiske teknologi, og samtidigt med at deres alternativer drejer sig om en udvik- ling af denne. Og ikke om, som de proklamerer, en kvalitativ ændring af den kapitalistiske teknologi. Som de borgerlige søger de at slå revolutionære marxister i hartkorn med KPisterne, der som bekendt med rette kan kritiseres for produktivkraftfetischisme. Og de gør det, uanset at de i deres egen forplumrede selvforståelse kun ser det fri samfund i ubrydelig og tæt omfavnelse af det stofskifte produktivkraftkategorien og teknologien retter sig imod.

Opnåelsen af frihedens rige forløber for dem ikke gennem frigørelsen fra den materielle produktion, men gennem den. Den teknologiske udvikling, som for marxister kun danner forudsætningen for menneskets realisering af sin menneskelighed, frigørelsen fra den materielle produktion og frigørelsen fra de materielle behovs dominans, omslutter de visioner om det alternative samfund vi bliver præsenteret for af nyreformisterne, og svinebinder mennesket som produktivkraft.

Jeg har med lys og lygte ledt efter udsagn om, hvad formålet med den perfektionerede teknologi er. Men min leden har været forgæves. Den perfektionerede teknologi, den 'anden' og 'anderledes' anvendte teknologi synes i sig selv at være formålet. Det er gennem den, i den, i den materielle produktion og behovstilfredsstillelse at frihedens rige findes. Det er først og fremmest i arbejdet, i den materielle produktion, at det 'frie' menneske skal realisere sin 'menne- 
skelighed', som det væsen der med sisyfosk stædighed søger at omslutte den totale natur gennem $\varnothing$ ko-kybernetisk regulering af denne.

Nyreformisterne kritiserer Marx og marxisterne for at mene, at den kapitalistiske udfoldelse af produktivkræfterne danner forudsætning for det kommunistiske samfund. Og for at hverken socialismen eller kommunismen trods en udfoldet produktivkraftudvikling endnu ikke er realiteter i denne verden. I måske forståelig ærgelse over denne realiteternes ondskab, kaster de sig ud i en overfladekritik af de kapitalistiske produktivkræfter og den kapitalistiske teknologi, som munder ud i en teoretisk perfektionering af disses inderste væsen, i en form som kan subsumeres kapitalen, og som efter borgerlig målestok måske kan kaldes mere human end den eksisterende form. Det er målet i sig selv. Disse ny produktivkræfter og denne ny teknologi skal ikke danne forudsætning for noget. De bærer lønnen i sig selv. Det er produktivkraftfetischisme så det forslår.

De har ikke forstået, at når Marx og marxisterne interesserer sig så levende for de samfundsmæssige produktivkræfter, så er det ikke for disses egen skyld. Det er p.g.a. deres problematiske form, det at de er underlagt kapitalistiske produktionsforhold. I virkeligheden er det ikke produktivkræfterne, som interesserer os marxister, men det som skal rejse sig på baggrund af disse. Vi interesserer os kun nødtvunget for produktivkræf- terne, vores egentlige interesse ligger uden for disses umiddelbare sfære. Den sfære, hvor med Marx' ord den menneskelige energiudvikling har sit mål i sig selv. Men vi ved, at før denne sfære kan udvikles frit, må de samfundsmæssige produktivkræfter udvikles til et stade og i en samfundsmæssig form, hvor de kan kontrolleres, giver anledning til et minimum af produktiv indsats og mister deres samfundsmæssige dominans.

Ho Chi-Minh har, så vidt jeg husker, engang udtalt, at menneskets materielle behov er få og enkle, mens dets åndelige behov er uendelige. Nyreformisterne fors $\varnothing$ ger at binde vor åndelige behovsudvikling og tilfredsstillelse til den materielle produktion. De knytter den samme forbindelse mellem materielle og åndelige behov, som er gældende i den kapitalistiske produktion, og de understøtter derfor i virkeligheden tanken om de materielle behovs udvikling og de åndeliges indespæring indenfor rammerne af, hvad der kan tilgodeses i den materielle produktion. Den materielle produktion er for dem ikke underlaget for de åndelige behovs udvikling. Den er den snærende ramme for disse sande menneskelige behovs udvikling.

Jeg vil lade Ho Chi-Minhs parole danne afslutningen på dette indlæg, da den enkelt udtrykker retningslinien for den revolutionære teoretiske indsats. Forståelsen af hvordan fremtidens kommunistiske samfund er et kvalitativt brud med kapitalismen og 
hele dens civilisatoriske baggrund. Hvordan kommunismen er det samfund, hvor den materielle samfundsmæssige reproduktion ikke længere er et problem, men grundlaget for de associerede individers frie udvikling, som omfatter den $\emptyset$ vrige naturs lige så fri udvikling.

\section{Litteratur:}

Rudolf Bahro: »Alternativet«, København, 1979, Suenson.

André Gorz: »Arbejderbevægelse og Nykapitalisme«, København, 1967, Gyldendal.

André Gorz: »Økologi og Frihed «, København, 1979, Politisk Revy.

André Gorz: »Abschied vom Proletariat«, Frankfurt, 1980, Europäische Verlagsanstalt.

Otto Ullrich: »Technik und Herrschaft«, Frankfurt, 1977, Suhrkamp.

Otto Ullrich: »Soziale Rolle in der Industrigesellschaft«, Münschen, 1978, Juventa Verlag.

Otto Ullrich: »Weltniveau«, Berlin, 1980, Rotbuch Verlag.

\section{Anders Lundkvist}

\section{Svar på en anmeldelse}

I sidste nummer af Kurasje (nr. 30) anmelder Peter Bundesen (PB) min bog »Kritik af privatarbejdet. 1. Del: Simpel vareproduktion « (jeg vil ile med at gøre opmærksom på at bogen er kommet på forlaget GMT og kun koster sølle $98 \mathrm{kr}$ for 346 sider!).

Den flg. kommentar er nødvendiggjort af at PB desværre har misforstået nogle grundlæggende tanker i bogen, hvorfor hans kritik i betydelig grad skyder ved siden af.

PB tillægger mig den absurde opfattelse, at det kun er i det usandsynlige særtilfælde, hvor alle privatarbejdere tjener lige præcis subsistensindtægten, at samfundet kan reproduceres; hvis der i et sådant samfund kommer et fad kaviar ind fra høj- re, vil samfundet bryde sammen! Jvf. AL set gennem PB's troldspejl: »Hvis indkomsterne stiger til over subsistensindkomsten vil det derimod være umuligt samfundsmæssigt at regulere det arbejde, der anvendes til produktionen af de forskellige varearter, hvorfor deres mængdemæssige fordeling vil være tilfældig « (Kur., s. 130), hvilket igen vil betyde at samfundet bryder sammen i anarki. Hvad, jeg skriver og mener er imidlertid noget helt andet. Nemlig: Samfundet (markedet) formår kun at sikre den allermest nødvendige deling af arbejdet (den der giver alle en subsistensindkomst), dvs. det kan ikke regulere overskudsarbejde (overskudsindkomst). Lad mig forklare nærmere. 